Revised version

Environmental Chemistry Letters 10, 1-4, 2012. doi : 10.1007/s10311-011-0333-3

Correspondence: Dr. Eric Lichtfouse, UMR1347 Agroécologie, 17, rue Sully, 21000 Dijon, France

Eric.Lichtfouse@dijon.inra.fr

\title{
Social Chemistry
}

\author{
Eric Lichtfouse ${ }^{1^{*}}$, Jan Schwarzbauer $^{2}$ and Didier Robert ${ }^{3}$
}

\begin{abstract}
1.INRA, UMR Microbiologie du Sol et de l'Environnement, BP 86510, 21065 Dijon Cedex, France. E-mail: Eric.Lichtfouse@dijon.inra.fr. *Corresponding author

2. RWTH Aachen University, Laboratory for organic-geochemical analysis, Institute of Geology and Geochemistry of Petroleum and Coal, Lochnerstr. 4-20, 52056 Aachen, Germany. E-mail: schwarzbauer@lek.rwth-aachen.de

3. European Laboratory for Catalysis and Surface Sciences, LMSPC, CNRS-UMR7515, Antenne de SaintAvold, UPV-Metz, Rue Victor Demange 57500 Saint-Avold. E-mail:drobert@univ-metz.fr
\end{abstract}

\begin{abstract}
This article is both an essay to propose social chemistry as a new scientific discipline, and a preface of the book Environmental Chemistry for a Sustainable World. Environmental chemistry is a fast emerging discipline aiming at the understanding the fate of pollutants in ecosystems and at designing novel processes that are safe for ecosystems. Past pollution should be cleaned,future pollution should be predicted and avoided (Lichtfouse et al., 2005a). Such advices are still not applied by humans as demonstrated by the Fukushima nuclear event and global warming. Human errors are repeatable.We therefore suggest a possible solution, which involves bridging chemistry and society by integrating social sciences in chemical research. In particular citizen discourse analysis should be useful to design chemicals that are both innovative and accepted by society. Then we present the recent success of environmental chemistry through the foundation of the Association of Chemistry and the Environment; the increase of the impact factor of Environmental Chemistry Letters from 0.814 in 2006 to 2.109 in 2009; and over 35,000 chapter downloads of the book Environmental Chemistry volume 1. Lastly we highlight major topics of the book Environmental Chemistry for a Sustainable World(Lichtfouse et al. 2012a,b). The book presents 23 chapters sorted into two parts: 1 . Nanotechnology and Health Risk, and 2. Remediation of Air and Water Pollution.
\end{abstract}

Keywords social chemistry; environmental chemistry; Fukushima; Chernobyl; climate change; society issues; pollutants; nanotechnology; health; water pollution; remediation; discourse analysis 
I was at a conference where someone said something about the Holocene. I suddenly thought this was wrong. The world has changed too much. So I said: 'No, we are in the Anthropocene.' I just made up the word on the spur of the moment. Everyone was shocked. But it seems to have stuck.

Nobel Prize-winner Paul Crutzen

\section{Fukushima, Chernobyl and Climate Change}

Nuclear plants on earthquake zones

Everybody has been recently shocked by the major accident of the nuclear power plant on March 31, 2011 at Fukushima, Japan. Such a failure was both unexpected and expected. Unexpected because most thought that the 1986 nuclear disaster at the power plant of Chernobyl, Ukraine, could never happen again, especially in wealthy, high technology countries such as Japan. Expected because geology tells us that Japan lies on the cusp of the Pacific-Philippine-Eurasian triple plate junction, where the complex interactions of three tectonic plates is unpredictable and loaded with potential activity. As a consequence, Japan experiences regular, high intensity earthquakes, tsunamis and volcanoes since centuries. Similarly to the Chernobyl global 'event', the release of radioactive pollutants from Fukushima nuclear plant in water, air, and soil will most probably severely affect human health, food security and economy worldwide for decades. Therefore, one might just ask why nuclear plants are built on such high-risk areas.

Human errors are repeatable

The global warming event has similar features - though less rapid and catastrophic -as the Chernobyl and Fukushima events on several rationales. First, the global warming is a worldwide event due notably to worldwide $\mathrm{CO}_{2}$ emissions (Lichtfouse, 2009a), a fact that is nicely coined by the popularsaying «pollutants have no borders ». Second, the effects of global warming are now clearly proven by many scientific trends (Feehan et al., 2009, Jones et al., 2009, Lavalle et al., 2009). Third, despite all such scientific evidence humans still use cars and planes that emit $\mathrm{CO}_{2}$; they practiceintensive, industrial agriculture that decrease soil carbon, and in turn emits $\mathrm{CO}_{2}$; they cut forest, which is turn emits $\mathrm{CO}_{2}$, and so on. Recent essays reports on global issues of and solution for society (Lichtfouse 2009a,b, 2010). From the scientist view, one might say ironically that "human errors are repeatable".

\section{Social chemistry}

If you can't address public perception, then it doesn't matter if you can afford the project, because it isn't going to happen.

Richard G. Luthy (Torrice M., 2011)

From those global issues several conclusions and advices can be drawn to improve society and the life of further generations. First, overwhelming scientific evidence is not sufficient to convince humans, notably decision-makers. Such a failure is due in particular to the lack of communication between science and society. In other words, scientists should not only publish in scholarly journals and attend high-level scientific meetings, but also communicate with the "real world". Here, a "social impact factor" to measure the impact of science on society - based for instance on web, facebook and blog usage data - would be very appreciated.

A second advice is that classical natural sciences such as chemistry, physics, biology, geology and medicine should integrate social, human and political sciences. In other words, the real world should be involved in the process of scientific discovery to bridge the gap between science and people. The integration of social disciplines is already occurring in agrosciences (Fleming and Vanclay, 2010, Karami E. and Keshavarz 2010, Lichtfouse 2010, Lichtfouse et al., 2009, 2010).Indeedagriculture has always been historically closer to the citizens, e.g. farmers, than chemistry and physics. The need for analysis of citizen discourses is nicely shown by the following survey answer: 
'What'ssustainable?You'vegottolookatourworldasweknowit.We'renotinasustainablepositionatthemom ent.That'swhyIsaywhatissustainable - I don't know.' (Fleming and Vanclay, 2010).

The concept of discourse was introduced in the 1960s by the French philosopher Michel Foucault. Foucault (1972) maintained that the way language is used has consequences for a whole range of things that go beyond the level of individuals or disciplines, to the very structures of society that shape and limit how people are able to speak, think, and act, and to the social structures that are developed accordingly. Now, environmental chemistry should use techniques of social sciences such as discourse analysis to discover novel findings that will be both innovative and accepted by citizens.

In 1871 the English biologist Thomas Huxley viewed society as a complex molecule in which atoms are represented by men, and that "social chemsitry" is what is called politics. He also made a statement that clearly highights society issues and the need to bridge science and people: "The great problem of social chemistry we call politics, is to discover what desires of mankind may be gratified, and what must be suppressed, if the highly complex compound, society, is to avoid decomposition."

\section{The success of Environmental Chemistry}

\section{Association of Chemistry and the Environment}

We founded the Association of Chemistry and the Environment (www.europeanace.com) in 2000 with a group of environmental scientists. A "chemistry flower" logo was designed to symbolise positive benefits of chemistry for Nature (Figure 1). The association was launched by the organisation of the two first European Meeting on Environmental Chemistry by Eric Lichtfouse, Brigitte Elbisserand coworkersin 2000 in Nancy, France, and in 2001 in Dijon, France. Meetings were immediately a success, with more than 300 attendants, due to several factors such as hard work from the organising team, willingness to create a new science community in a highly conservative science system, and gathering in a friendly location scientists from various isolated disciplines such as soil science, toxicology and chemistry. The first presidents of the association were Eric Lichtfouse (2000-2004) and Jan Schwarzbauer (2005-2009). Noteworthy, well establishedassociations, in particular the Division of Environmental Chemistry and the Division of Geochemistry of the American Chemical Society (ACS), supported us, in particular by organising joint symposia sponsored by the petroleum research fund. We therefore thank very much the American Chemical Society.

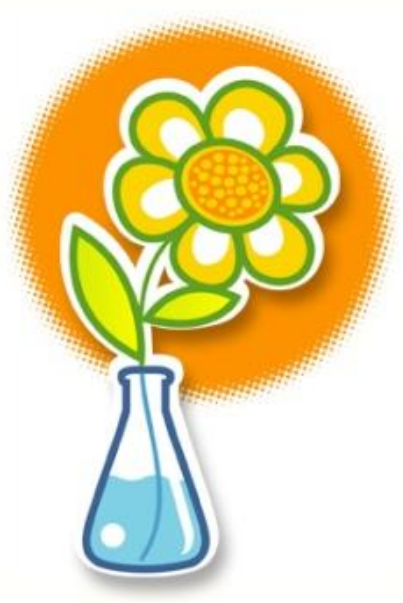

Figure 1.The "chemistry flower" was designed by Eric Lichtfouse and Guillaume Decaux to symbolise positive benefits of chemistry for Nature. Guillaume Decaux is a professional drawer living in Strasbourg, France (http://www.alcide.fr/). 
We founded the journal Environmental Chemistry Letters (www.springer.com/10311)in 2003 to fill the science gap between chemistry and environment. Despite a tough selection by the Thomson Reuters agency (www.thomsonreuters.com) to enter the Science Citation Index, we got our first impact factor of 0.814 for 2006, only 3 years later. The impact factor increasedsteadily to reach 2.109 in 2009 (Figure 2). The increase of the impact factor can be explained by a higher quality of articles, as a result of higher rejection that reached $73 \%$ in 2009 . Given the rapid increase of submitted articles, more that $70 \%$ of articles are now declined at pre-screening stage. Journal articles are highly viewed as proven by the number of pdf downloads that reached 36,549 in 2009 (100 per day). This finding is both unexpected and expected. Unexpected because most articles are not in open access. Expected because Springer has about 30 millions scientists who access articles. Here, contrarily to the common thinking, articles published in restricted access by a major publisher are probably much more visible than open access articles published by a minor publisher.

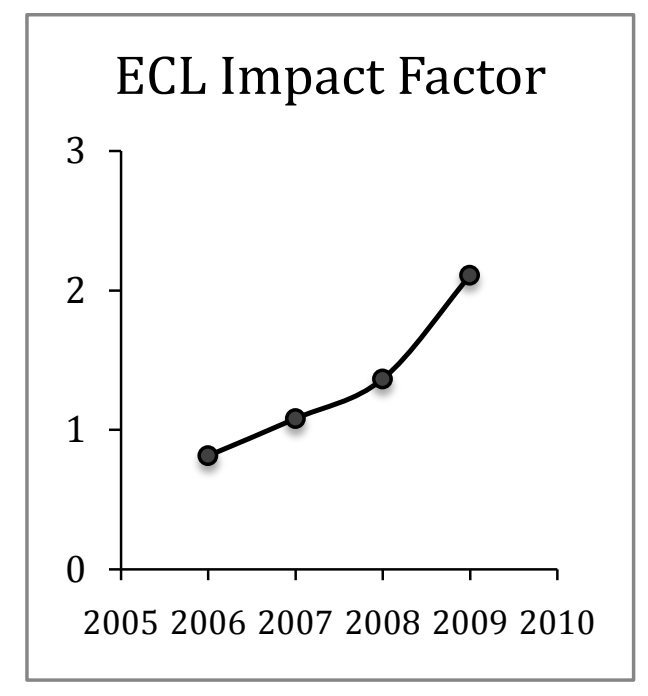

Figure 2. The impact factor of the journal Environmental Chemistry Letters (ECL) increased from 0.814 in 2006 to 2.109 in 2009. Article pdf downloads reached 36,549 in 2009 (100 per day).

\section{Environmental Chemistry}

We published the book Environmental Chemistry in 2005 (Lichtfouse et al., 2005b). The book includes 69 chapters sorted in 7 sections: Analytical Chemistry, Toxic Metals, Organic Pollutants, Polycyclic Aromatic Hydrocarbons, Pesticides, Green Chemistry, and Ecotoxicology. The book is a success with over 35,000chapter downloads from 2007 to 2010. Book chapters are still highly downloaded with 639 downloads in January 2011 ( 20 per day). The highest recent downloads can be freely viewed at Springer Realtime (www.realtime.springer.com). Here the most popular topics are heavy metals, bioremediation and green chemistry.

\section{Environmental Chemistry for a Sustainable World}

This new book series presents 23 chapters published into 2 volumes: Nanotechnology and Health Risk (Lichtfouse et al., 2012a), and Remediation of Air and Water Pollution (Lichtfouse et al., 2012b). Table 1 allows fast access to chapters by topics. All chapters have been reviewed and the rejection rate was $15 \%$. The Nanotechnology section highlights carbon nanotubes for energy and detection; cyclodextrins for pollutant trapping; magnetic nanophotocatalysts for pollutant degradation; and polysaccharides for metal oxide green synthesis. The Health Risk section describes new findings on 
the old DDT pesticide;geochronology of river pollutants; toxic effects of endocrine disruptors; and heavy metals in seafood. The Air and Water Pollution section presents the selective degradation of chiral pharmaceuticals; the alteration of housing walls by $\mathrm{CO}_{2}, \mathrm{SO}_{2}$ and $\mathrm{NOx}$; cleaning industrial waste gas and dyes wastewater; methods to extract and detect pollutants; and harmful chlorinated pollutants. The Remediation section highlights the electrochemical degradation of pharmaceuticals; methods to treat biogas $\mathrm{CO}_{2}, \mathrm{CH}_{4}, \mathrm{H}_{2} \mathrm{~S}$ and $\mathrm{NH}_{4}$; heavy metal sequestration on biomass and soil nodules; As phytoremediation; and photocatalytic inactivation of water microbial pathogens.

Table 1. Chapters of the books Environmental Chemistry for a Sustainable World, volume 1 and 2 (Lichtfouse et al. 2012a,b). Keywords and DOI for fast access.DDT : 2,2,-bis(4-chlorophenyl)-1,1,1trichlorethane. PCBs : polychorinated biphenyls. VOCs : volatile organic compounds.

\begin{tabular}{|c|c|c|c|c|}
\hline \multicolumn{3}{|c|}{ Keywords } & $1^{\text {st }}$ author & DOI \\
\hline Nanotubes & Energy & Water & Tan & $10.1007 / 978-94-007-2442-6 \_1$ \\
\hline Cyclodextrin & Sequestration & Water & Landy & $10.1007 / 978-94-007-2442-6 \_2$ \\
\hline Nanotubes & Energy & Sensors & Chauhan & $10.1007 / 978-94-007-2442-6 \_3$ \\
\hline Photocatalysis & Remediation & Water & Liu & $10.1007 / 978-94-007-2442-6 \_4$ \\
\hline Polysaccharides & Metal oxides & Green chemistry & Visinescu & $10.1007 / 978-94-007-2442-6 \_5$ \\
\hline DDT isomers & Remediation & Pesticides & Ricking & $10.1007 / 978-94-007-2442-6 \_6$ \\
\hline Geochronolgy & Pollution history & Sediments & Heim & $10.1007 / 978-94-007-2442-6 \_7$ \\
\hline Endocrine disruptors & Toxicity & Pesticides & Anupama & $10.1007 / 978-94-007-2442-6 \_8$ \\
\hline Heavy metal & Toxicity & Seafood & Stankovic & $10.1007 / 978-94-007-2442-69$ \\
\hline DDT, PCBs & Toxicity & Seafood & Sarkar & $10.1007 / 978-94-007-2442-6 \_10$ \\
\hline Pharmaceuticals & Remediation & Water & Ribeiro & $10.1007 / 978-94-007-2439-6 \_1$ \\
\hline Buildings & $\mathrm{CO}_{2}, \mathrm{SO}_{2}, \mathrm{NO}_{\mathrm{x}}$ & Air & Sanjurjo & $10.1007 / 978-94-007-2439-6 \_2$ \\
\hline Bioreactors & Remediation & VOCs & Rene & $10.1007 / 978-94-007-2439-6 \_3$ \\
\hline Extraction & Pollutants & Water & Etxebarria & $10.1007 / 978-94-007-2439-6 \_4$ \\
\hline $\mathrm{ClO}_{2}, \mathrm{R}-\mathrm{Cl}$ & Oxidation & Water & Sharma & $10.1007 / 978-94-007-2439-6 \_5$ \\
\hline Dyes & Biodegradation & Water & Mondal & $10.1007 / 978-94-007-2439-6 \_6$ \\
\hline Heavy metals & Lichens & Air & Shukla & 10.1007/978-94-007-2439-6_7 \\
\hline Pharmaceuticals & Remediation & Water & Brillas & $10.1007 / 978-94-007-2439-6 \quad 8$ \\
\hline Biogas & Cleaning & $\mathrm{CO}_{2}, \mathrm{H}_{2} \mathrm{~S}, \mathrm{R}-\mathrm{Cl}$ & López & $10.1007 / 978-94-007-2439-6 \_9$ \\
\hline Heavy metals & Toxicity & Biosorption & Mudhoo & $10.1007 / 978-94-007-2439-6 \_10$ \\
\hline Heavy metals & Sequestration & Nodules, soil & Gasparatos & 10.1007/978-94-007-2439-6_11 \\
\hline Arsenic & Remediation & Biosorption & Dabrowska & 10.1007/978-94-007-2439-6_12 \\
\hline Photocatalysis & Microbes & Disinfection & Mahmood & 10.1007/978-94-007-2439-6_13 \\
\hline
\end{tabular}

\section{References}

Feehan J., Harley M., Minnen J. (2009) Climate change in Europe. 1. Impact on terrestrial ecosystems and biodiversity. A review . Agronomy for Sustainable Development29, 409-421. DOI: 10.1051/agro:2008066.

Foucault M. (1972) The Archaeology of Knowledge: And The Discourse on Language. Tavistock Publications Ltd. 249 p. ISBN 0-415-28753-7

Jones A., Stolbovoy V., Rusco E., Gentile A.R., Gardi C., Marechal B., Montanarella L. (2009) Climate change in Europe. 2. Impact on soil. A review. Agronomy for Sustainable Development 29, 423-432. DOI:

10.1051/agro:2008067.

Karami E., Keshavarz M. (2010) Sociology of sustainable agriculture. In Lichtfouse E. (ed.), Sociology, Organic Farming, Climate Change and Soil Science. Sustainable Agriculture Reviews 3, 19-40. DOI:10.1007/978-90481-3333-8

Lavalle C., Micale F., Durrant Houston T., Camia A., Hiederer R., Lazar C., Conte C., Amatulli G., Genovese G. (2009) Climate change in Europe. 3. Impact on agriculture and forestry. A review . Agronomy for Sustainable Development 29 (2009) 433-446. DOI: 10.1051/agro/2008068 
Lichtfouse E. (2009a) Climate change, society issues and sustainable agriculture. In Lichtfouse E. (ed.) Climate Change, Intercropping, Pest Control and Beneficial Microorganisms. Sustainable Agriculture Reviews 2, 1-7. DOI : 10.1007/978-90-481-2716-0_1

Lichtfouse E. (2009b) Sustainable Agriculture as a Central Science to Solve Global Society Issues. In Lichtfouse E. (ed.) OrganicFarming, PestControl and Remediation of Soil Pollutants. Sustainable Agriculture Reviews 1, 13. DOI: 10.1007/978-1-4020-9654-91

Lichtfouse E. (2010) Society issues, painkiller solutions, dependence and sustainable agriculture. In Lichtfouse E. (ed.), Sociology, Organic Farming, Climate Change and Soil Science. Sustainable Agriculture Reviews 3, 1-17. DOI: 10.1007/978-90-481-3333-8_1

Lichtfouse E., Hamelin M., Navarrete M., Debaeke P., Henri A. (2010) Emerging agroscience. Agronomy for Sustainable Development 29, 1-10. DOI: 10.1051/agro/200955

Lichtfouse E., Navarrete M., Debaeke P., Souchère V., Alberola C., Ménassieu J. (2009). Agronomy for sustainable agriculture. A review. Agronomy for Sustainable Development 29, 1-6, 2009. DOI: 10.1051/agro:2008054

Lichtfouse E., Schwarzbauer J., Robert D. (2005a) Preface. In Lichtfouse E., Schwarzbauer J., Robert D. (eds.) Environmental Chemistry. p. V. Springer. DOI: 10.1007/b137751

Lichtfouse E., Schwarzbauer J., Robert D. (2005b) (eds.) Environmental Chemistry. Volume 1, p. V. Springer. ISBN 978-3-540-22860-8. DOI: 10.1007/b137751

Lichtfouse E., Schwarzbauer J., Robert D. (2012a) Environmental Chemistry for a Sustainable World. Vol. 1:Nanotechnology and Health Risk. Springer, 458 p. doi:10.1007/978-94-007-2442-6

Lichtfouse E., Schwarzbauer J., Robert D. (2012b) Environmental Chemistry for a Sustainable World. Vol. 2: Remediation of Air and Water Pollution. Springer, 562 p. doi:10.1007/978-94-256007-2439-6

Fleming A., Vanclay F. (2010). Farmer responses to climate change and sustainable agriculture. A review. Agronomy for Sustainable Development 30, 11-19. DOI: 10.1051/agro/2009028

Torrice M. (2011) Challenges to water reuse. Chemical and EngineeringNews, April 25, 38-39. 